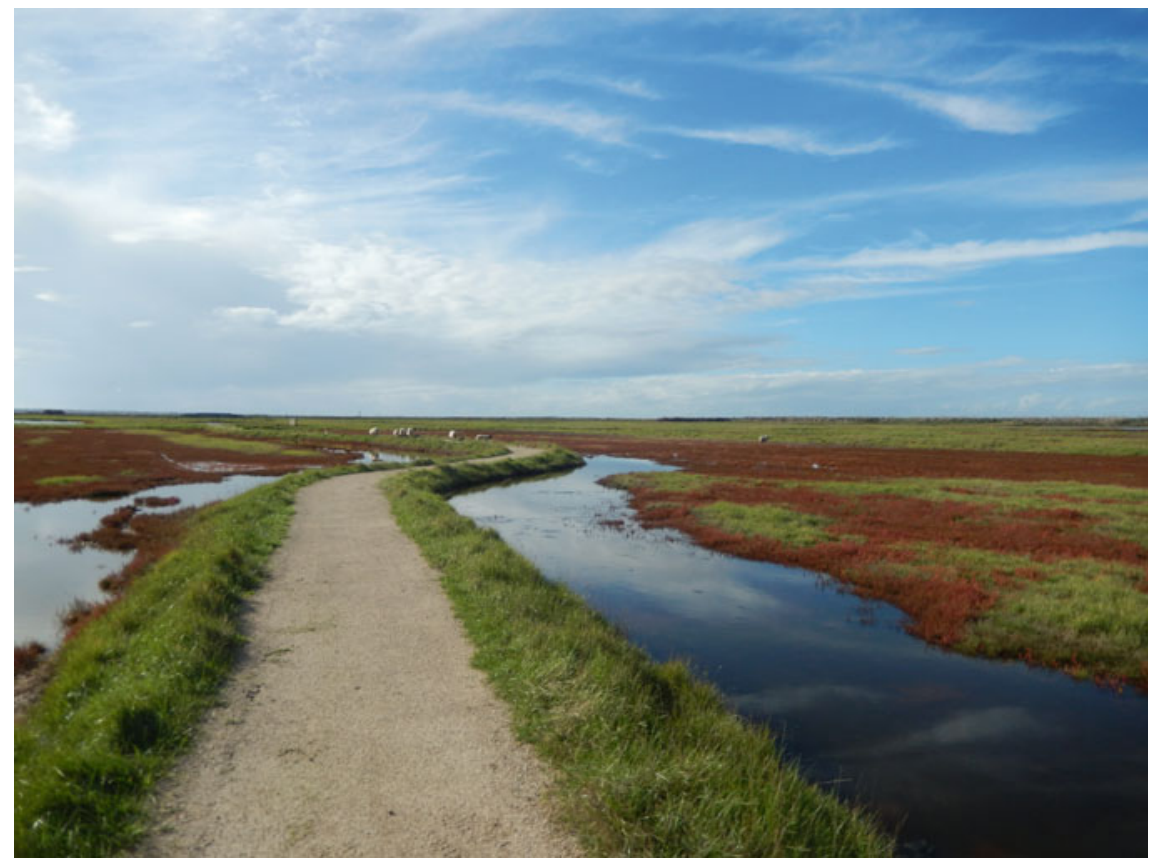

The path of the polders in the natural reserve Moëze-Oléron in Saint-Froult, Charente-Maritime, France, Wikimedia, KiwiNeko14, released under a Creative Commons Attribution-Share Alike 4.0 International license 


\title{
Chapter 12 \\ Europolders a European Program \\ on Polder Landscape, Heritage, and Innovation
}

\author{
Hildebrand P. G. de Boer
}

\begin{abstract}
Since the twelfth century, polder landscapes have characterized the Netherlands, in particular, but also have appeared across Europe-vast plains reclaimed from water and repurposed for crops and livestock, farmers and rural communities. Over the centuries, urbanization has brought domestic and international visitors seeking leisure activities in these cultural landscapes. But polders have lain mostly in the shade, as it were, of other landscapes, merely a link between hills, dunes, ocean beaches, and historic cities. The Europolders Program emancipates this characteristic landscape, and strengthens prosperity in it, showing it to be an attractive and interesting territory. The Netherlands has a remarkable hydraulic engineering reputation abroad, not only because of work they have done at home-to endless extraction, reclamation and drainage, irrigation projects, dyke, channel, and harbor works - but also because they brought their expertise to the farthest corners of the world. Polders across Europe were shaped or at least influenced by Dutch (Frisian, Hollanders, Zeeuw) and Flemish people. The Europolders Program focuses on developing a European network of polder landscapes with extensive cultural and natural value. It aims to increase the accessibility, visibility, and awareness of historical polder landscapes, water management, and technological innovation, for the benefit of residents and visitors, and to strengthen regional economies.
\end{abstract}

Keywords Polders $\cdot$ European landscape $\cdot$ European network $\cdot$ Cultural value Accessibility $\cdot$ Awareness $\cdot$ Public support $\cdot$ Economic value

\footnotetext{
H. P. G. de Boer $(\bowtie)$

Dutch Foundation for Industrial Culture, Amsterdam, The Netherlands

e-mail: hildebranddeboer@hotmail.com 


\section{Introduction}

After the Early Middle Ages, around 1000 AD, a new period of economic development in the Netherlands led to a population jump, from about 200.000 inhabitants to more than 800.000 inhabitants in 1300 (Malanima 2010, 5-6). The increasing need for living space and nourishment necessitated major land reclamation in the low, western half of the Netherlands. Fen- and peatlands were drained by draining ditches, which caused the soil to subside, so that extensive construction of dykes became necessary, in combination with sluices, windmills, mechanized pumping works, and drains. Dutch experience in water management techniques, gained during many centuries, diffused to the rest of Europe with travelers: Frisian, Dutch, Zeeuw and Flemish farmers, dyke workers, monks, colonists, engineers, contractors, concessionaires, and capital providers took it to Germany, Poland, England, France, Italy, and Ukraine. Among them, the Netherlands and its people played a historically distinctive role in this land reclamation (Danner et al. 2005, 27-29). Today, many polders still host farmers and rural communities, although city dwellers settling in and around the polders increasingly demand leisure activities, in conjunction with domestic and international tourists celebrating this cultural landscape.

A range of distinctive features makes historical polder systems resilient. They offer active control (water management), accessibility by land and water, multifunctionality for residents and visitors, adaptability to current and future needs (from changes in agriculture and urbanization to climate change), and a distinctive identity (natural and cultural values, combination of cultural landscape and wilderness, cooperation between inhabitants). Yet polders lie mostly in the shade of other landscapes, as it were, merely a link between hills, dunes, ocean beaches, and historic cities. The Europolders Program intends to emancipate them as an important European landscape, and as an attractive and interesting territory for domestic and international tourism. The Program focuses on developing a European network of polder landscapes with extensive cultural and natural value. The aim is to expand its accessibility and visibility while benefitting regional economies. It will ensure that each Europolder will link to a regional network of other historical and innovative sites; each will have an Information Point (for example, a Waterways Museum) explaining each important heritage site or new site related to the polder. In short, the Europolder Program intends to provide a comprehensive view of the story of the polder.

Public support from residents and visitors is a prerequisite for sustainable conservation of this natural and cultural heritage, and for the adoption of policy measures protecting it. Local governments and regional water authorities should apply these measures through inclusive development, with constant awareness of the historical genesis of the cultural landscape, its cultural and economic activity.

Historically, citizens and government in most polders periodically collaborated to guarantee responsible water management, such as keeping watercourses and their banks clean for effective water drainage. This collective work was developed in combination with financial levies by the authorities on citizens, to maintain operations - such as dykes and pumping stations — in an operationally responsible manner. 
Such physical and financial efforts are still typical of life in polder landscapes. In addition, polder communities, in cooperation with the authorities, can focus on stimulating awareness by making cultural history recognizable to community members and outsiders alike. Initiatives to restore and reallocate polder monuments-including historic mills, pumping stations, quays, farms, and agricultural production buildings - go hand in hand with an increasing number of hospitality facilities for visitors.

The aim is not only to promote day-trip tourism, but also to stimulate residential tourism as a relevant economic factor. This has become a matter of course in a polder like the UNESCO World Heritage Beemster. The intensive exposure of the Beemster, combined with excellent accommodation options, makes it a valued travel destination and starting point for longer stays in the region. This approach in the Beemster and other polder areas that have already been opened up, such as the French Marais de Poitevin or the Holland Fen in England, will work well in the polder areas in the Europolders Program that are not yet fully accessible.

\section{Earlier Regional Networks}

The Europolders Program is based on earlier systems of regional networks of industrial and engineering heritage. An early regional network in the Ruhr area, the Route der Industriekultur (Route of Industrial Culture) inspired its basic structure, a tourism route connecting heritage networks that share a theme. It was part of the program for the 1989 Internationale Bau Austellung (International Architectural Exhibitition), and continuing the IBA's history of displaying new concepts and inventions. In turn, the Route sparked the 1999 European Route of Industrial Heritage (ERIH): it linked eighteen regional networks in Germany, Poland, Austria, Spain, UK, Belgium, Luxembourg, the Netherlands; more than 100 ERIH-Anchor Points; and about 1800 other European industrial heritage sites. Several more regional networks are in preparation, including the German-Dutch EuregioNetwork Industrial Culture and the RotterdamDelta Network for industrial heritage and innovative industries.

One of the ERIH regional networks, the HollandRoute in the Amsterdam Metropolitan Area, was officially opened on 1 July, 2011 by the Commissioner of the King. The HollandRoute takes tourists and recreationists to heritage sites of trade, industry, commerce, engineering, agrarian culture, water management and (military) infrastructure in the Province of North-Holland, all in relation to the local polder landscapes. The HollandRoute currently has six ERIH-Anchor Points, or themed attractions, most of them focusing on water heritage in one way or another: the Heineken Experience, the Dutch Maritime Museum, Zaanse Schans (an open-air museum of a Dutch village), Museum Pumping Station De Cruquius, Museum Steam Tram Hoorn-Medemblik, and the Dutch Steam Machine Museum in the pumping house of the "Vier Noorder Koggen" polder district in Medemblik. Dozens of HollandRoute Points are local historical sites, including windmills and pumping stations. Places to eat, drink, and sleep are Rest Points, all located in historic buildings related to industrial heritage and in the polder landscape. Most Anchor Points, Route Points, 


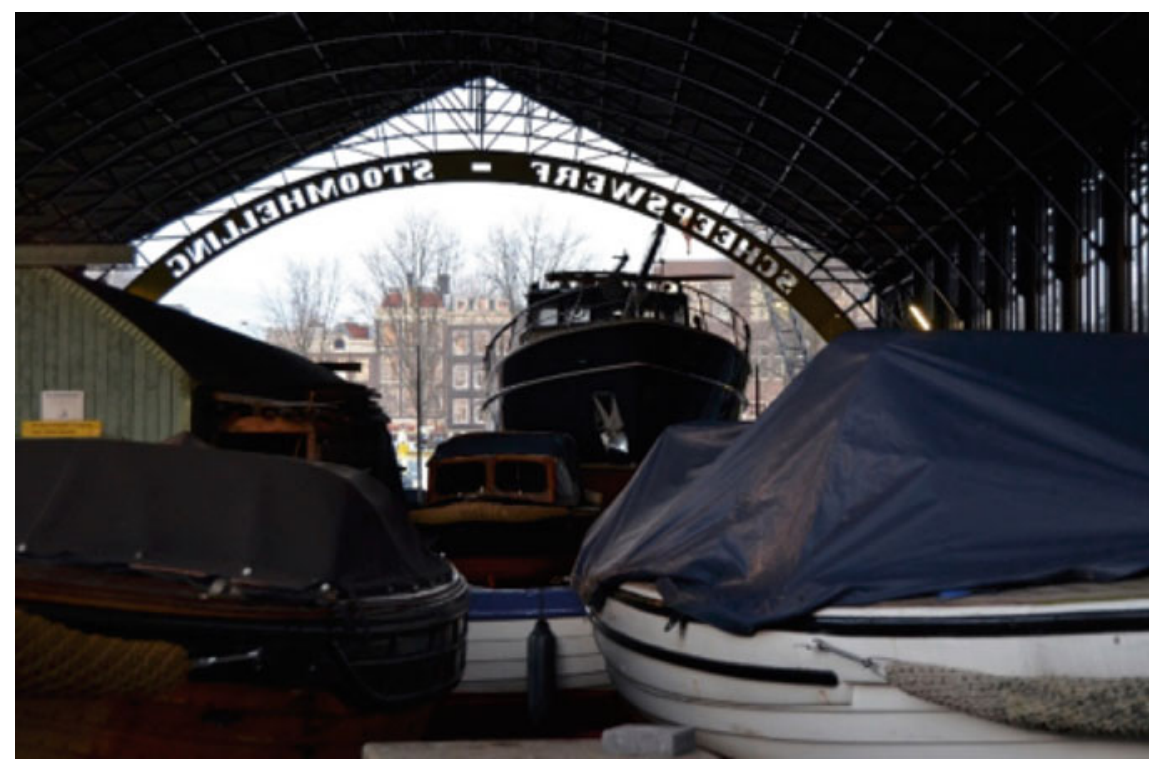

Fig. 1 Anchor Point, HollandRoute, Kromhout Shipyard, Amsterdam (Photograph: De Boer); released under a Creative Commons Attribution-NonCommercial-NoDerivatives 4.0 International License

and Rest Points are along either the main route or theme routes for cycling, hiking, and boating. Water-related attractions on the HollandRoute include historic waterways, locks, bridges, dykes, shipbuilding and other maritime trade sites, military defense structures, fisheries, and harbors (Figs. 1 and 2). The HollandRoute brings a wider range of visitors than many local attractions, because its associated infrastructure is equally distributed across the Metropolitan Region of Amsterdam. The HollandRoute focuses on both domestic leisure and inward tourism.

In 2013, the Dutch developed a plan to extend the HollandRoute with a new network, the HollandRoute Polderland Network. A coherent heritage network across Westfriesland, Waterland, Zaan Area, Amsterdam, and Amstel-Meer, it will showcase the comprehensive, cultural, and environmental polder heritage of the western part of the Netherlands. In a few years, visitors will be able to see and learn about the many features of Holland Polderland in their historical and functional context: dykes, ring canals, drainage ditches, land reclamation, windmills, pumping stations, locks, canals, ditches, bridges, fore polders, peat polders, clay polders, peat extraction, polder roads, railways, tramways, land use, farms, agriculture, urbanism, water authority buildings, polder maintenance buildings, and ecology (Figs. 3, 4, 5 and 6). Making the heritage recognizable to a broad audience of citizens and visitors will strengthen their experience of its history.

History is one side of the coin: the other side of the coin is the future progress that determines the sustainable conservation of the heritage, as well as the implementation 


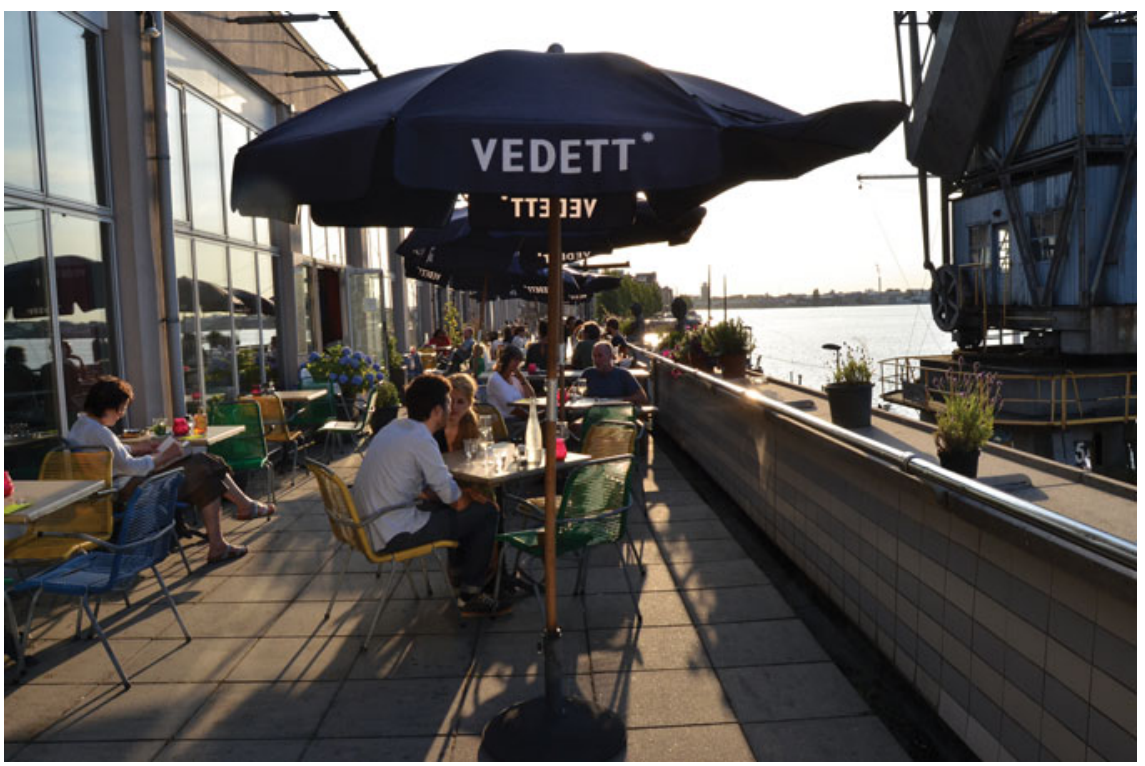

Fig. 2 Rest Point, HollandRoute, Kompaszaal, Amsterdam, former arrival and departure hall of the Royal Dutch Steamboat Company (Photograph: De Boer); released under a Creative Commons Attribution-NonCommercial-NoDerivatives 4.0 International License

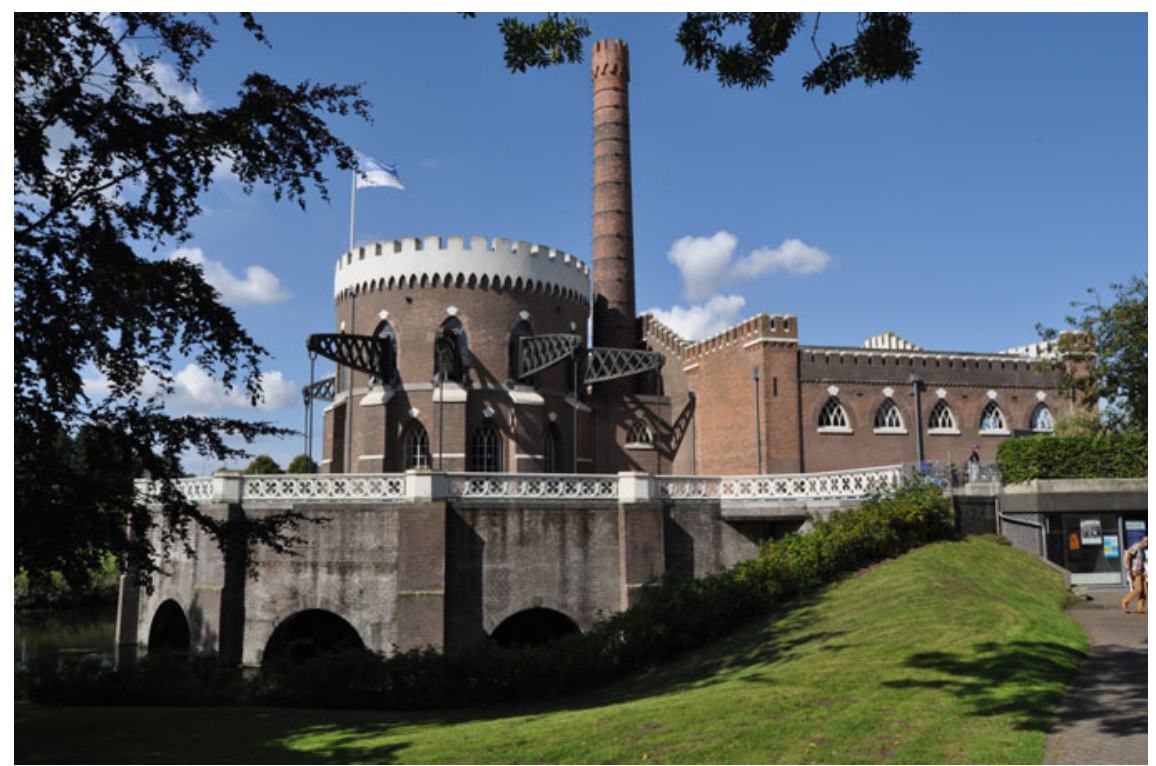

Fig. 3 HollandRoute Polderland Anchor Points Cruquius Steam Pumping House (Photograph: De Boer); released under a Creative Commons Attribution-NonCommercial-NoDerivatives 4.0 International License 


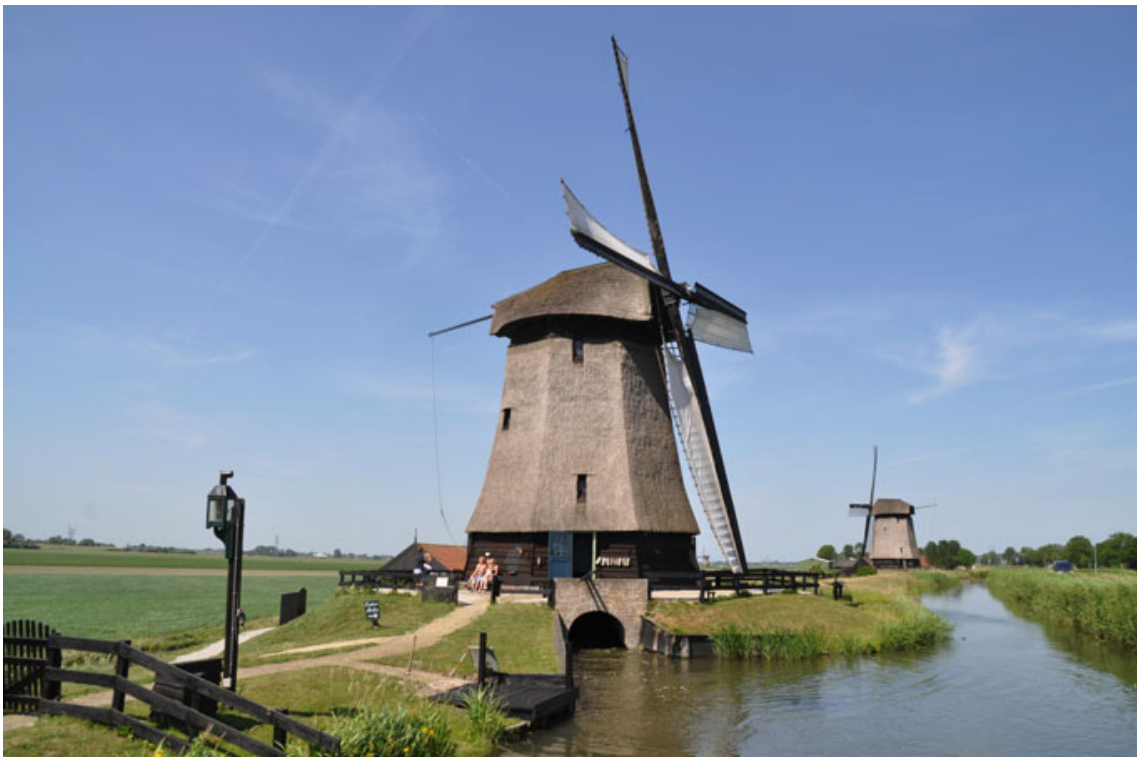

Fig. 4 HollandRoute Polderland Schermer Museum Mill (Photograph: De Boer); released under a Creative Commons Attribution-NonCommercial-NoDerivatives 4.0 International License

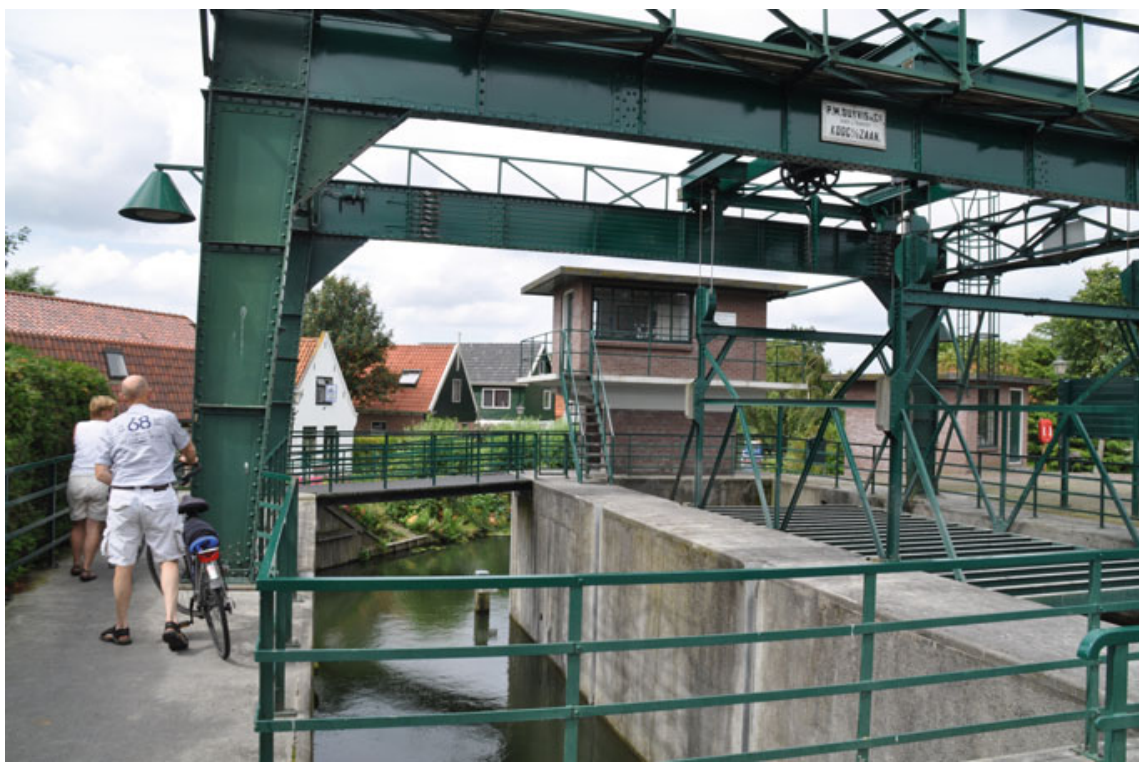

Fig. 5 HollandRoute Polderland, Polder Point, Broekerhaven Boat Lift (Photograph: De Boer); released under a Creative Commons Attribution-NonCommercial-NoDerivatives 4.0 International License 


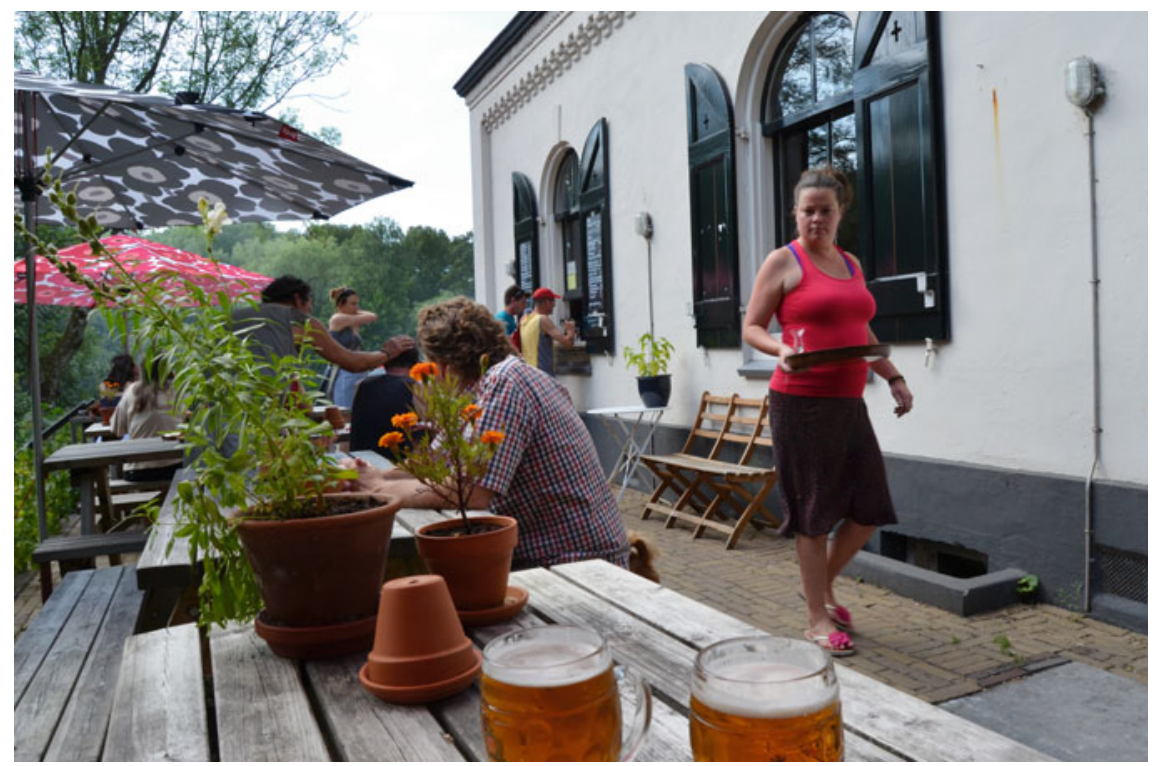

Fig. 6 HollandRoute Polderland, Rest Point Pumping House, Amsterdam Flevopark (Photograph: De Boer); released under a Creative Commons Attribution-NonCommercial-NoDerivatives 4.0 International License

of historic values in new interventions. Think of the possible restoration of former watercourses and quays, paths, polder parcels, fruit gardens, trees, or redevelopment of agricultural, industrial and engineering heritage. New interventions might in many cases be unavoidable, because of climate issues, sea level rise, groundwater silting, economic changes in agriculture, food security, and further urbanization. Heritage counts in this future agenda, because it makes recognizable the ongoing historical dynamics of a polder community and the particular ecological conditions of the polder biotope. Even in the midst of progress, a historical perspective should be valued. Only then it will remain manifest for citizens and visitors, in tangible heritage such as the HollandRoute Polderland Network (see photographs of Cruquius Steam Pomp and Schermer Museum Mill).

\section{From HollandRoute Polderland to Europolders Program}

In 2014, the Provincial Government of North-Holland and the HollandRoute Foundation concluded that the HollandRoute Polderland Network could be embedded in a wider European context, raising awareness of polder landscapes and their cultural and natural heritage. They foresaw a European network of polder landscapes, with historical connections to the activities of the Dutch (Frisian, Hollanders, Zeeuw) and 
Flemish. Such a network would map a number of historical dynamics with emphasis on the period between 1100 (the earliest land reclamation in Northern Germany) and about 1875 (the latest land reclamation and settlement of Mennonite communities in Ukraine) (Danner et al. 2005, 11). It would study the influx of Dutch capital and the use of financial arrangements to finance various water management projects and explore the role of Dutch and Flemish engineers, investors and settlers in a number of major water management projects, acting as intermediaries between the Low Countries and the host countries. The network would track the Dutch presence, or footprints across the landscape, in sluices, canals, mills, dykes, settlements, and other tangible heritage. The countries involved would be the Netherlands, Belgium, France, Italy, UK, Germany, Poland, and Ukraine. This idea is the heart of the emergent Europolders Program.

As in the HollandRoute Polderland Network, the ambition of Europolders is to interlink the involved polder areas not only on the basis of a common history but also the challenges of the future. Those challenges include sustainably conserving the heritage itself, as well as incorporating historic values in new developments to attract the interest of residents and visitors. The Europolder networks reveal unusual new landscapes to both international tourists and urban holidaymakers; several Europolders are historically related to nearby cities, or even to the urban food supply. In most parts of Europe, tourism and recreation are continuous economic growth factors, even though economic crises; a growing interest in cultural-historical tourism and cultural landscapes confirms the strategic value of the Europolders Program for European cooperation (Fig. 7 see map).

Today, an effective agenda for better regulation and innovation of the polders landscapes should not only focus internally on heritage and water issues, but also look outward to market polders to city populations as a cultural and natural outlet. Polder landscapes in urban areas, such as Hamburg, Gdańsk, Bordeaux, Venice, and Amsterdam can do this easily. The Europolders Program can be a building block for such innovation and for improving tourists' access to the culturally and naturally valuable polder landscape.

The Gdańsk (Danzig) and Malbork (Marienburg) Marshlands, in the delta of Vistula and Nogat, have been plagued by floods over the course of history. The floods of 1540 and 1543 made the area unusable and inaccessible for a long time. The nearby city of Gdańsk was growing, and its city council decided to turn the wetland into agricultural land to secure their food supply. This period coincides with the rise of the Mennonites in Friesland. Foreman Menno Simons joined the Swiss Anabaptists in 1531; in 1536, he broke with the Roman Catholic Church and fled with his followers to Groningen and Eastern Friesland, and later to Schleswig-Holstein to escape prosecution. Many of the Mennonites were farmers looking for land to cultivate.

On 28 November, 1547, the Gdańsk city council granted the village and estate of Reichenberg (Rychemberk) to Philippus Edzema, and granted him permission to settle it with people of his nationality (Dutch) (Global Anabaptist Mennonite Encyclopedia Online). This was the beginning of decades of colonization. Between 


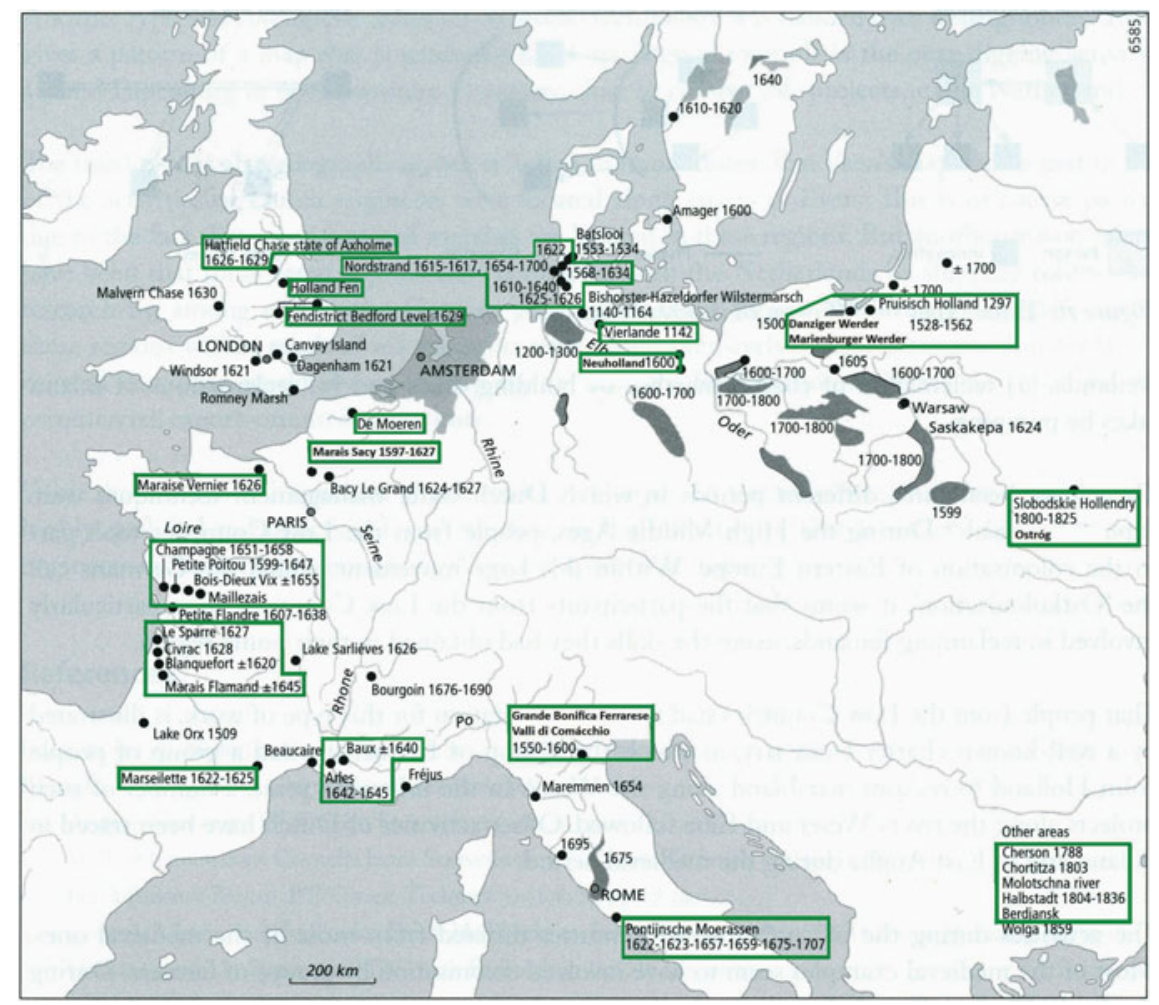

Fig. 7 Locations of the Europolder Areas (within the green lines) on the Indicative List (after: Van Veen 1962, 54). Aspects of Europolders: Example Poland); released under a Creative Commons Attribution-NonCommercial-NoDerivatives 4.0 International License

1547 and 161510.000 to 11.000 immigrants arrived in the delta (Dr. Zbigniew Chodyla in Danner et al. 2005, 36). As historian Zbigniew Chodyla later wrote:

Thanks to the Dutch, the major elements of hydraulic systems were constructed, such as main and local flood control embankments, drainage canals and ditches, dikes and sluices (Fig. 8), ponds, bullock gears, and in particular bucket windmills. In addition, they planted belts of trees and bushes in the fields and introduced braided fences. (Dr. Zbigniew Chodyla in Danner et al. 2005, 42)

In this way, an estimated more than 100.000 ha of agricultural land was developed in the Gdańsk and Malbork area (in all Poland about 255.000 ha) from 1547 to 1800, exploited by the Mennonites as free farmers with the consent of the Polish authorities for grain, cattle, and horses. The colonists built farmhouses and villages with churches and graveyards (Figs. 9, 10 and 11) (Dr. Zbigniew Chodyla in Danner et al. 2005, 37). Some became entrepreneurs in trade and export, or in the processing of agricultural products. Their trade went through the domestic market and export market in Gdańsk. 


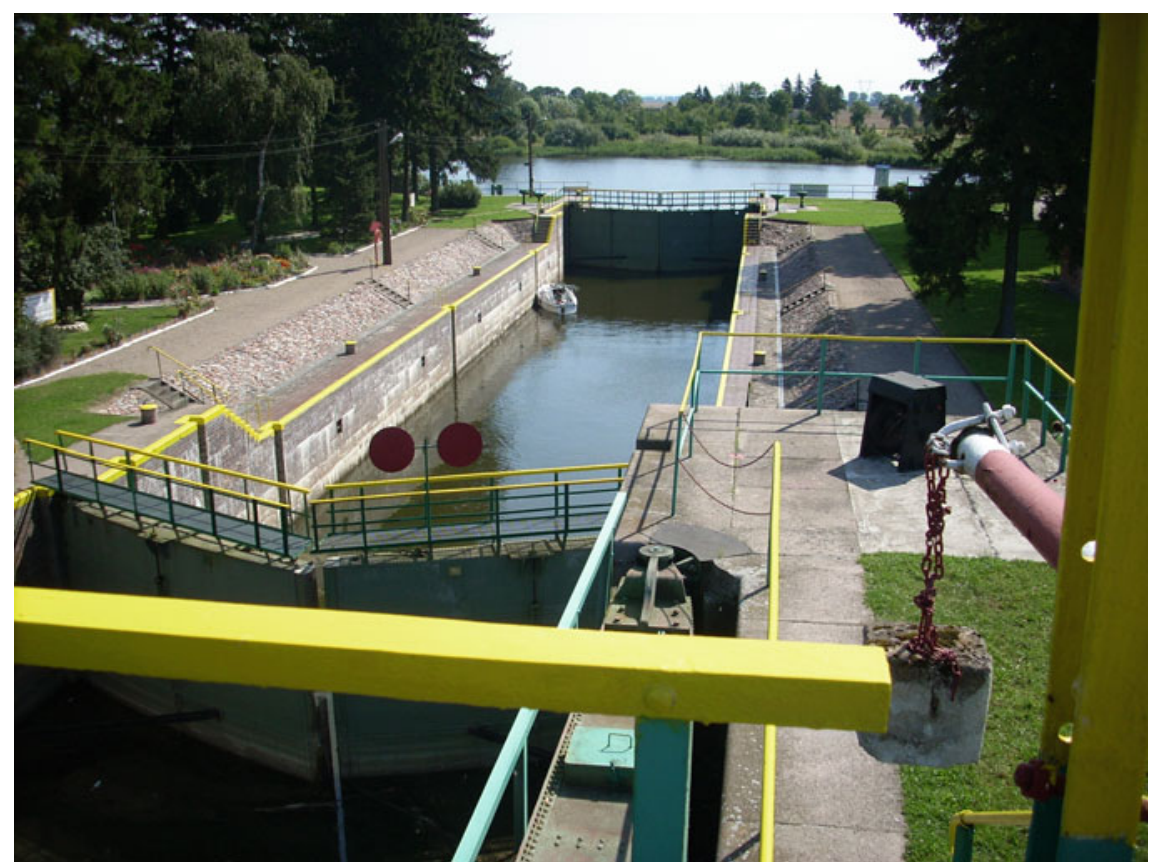

Fig. 8 Vistula lock at Szkarpawa (Photograph: De Boer); released under a Creative Commons Attribution-NonCommercial-NoDerivatives 4.0 International License

Today, several production buildings are recognizable in the area between Vistula and Nogat, for example, the maltery of the Danziger Aktienbrauerei in Nowy Staw (Neuteich) (Fig. 12), the dairy, and parts of the liquor factory of Heinrich Stobbe in Nowy Dwor Gdański (Tiegenhof). During the nineteenth century, a dense rail infrastructure was established: narrow gauge connections, stations, water towers, and bridges (Fig. 13).

All these tangible elements of heritage can rather easily be used to make the area's fascinating history recognizable to citizens and visitors. The core of this recognition will be the Polder Information Point in the Zulawsky Museum Park, in and around the former dairy at Nowy Dwor, in association with a historical society (Klub Nowodworski). From this Point, history can be linked with innovative local developments, with an emphasis on water management and water technology, in association with the Regional Water Management Board Gdánsk (Regionalny Zarząd Gospodarki Wodnej w Gdańsku).

Across the Europolder Program, the historical and innovative aspects of each polder itself, visible in objects and spatial structures, will be part of a regional polder network and connected by different sorts of trails. The Main Connection trail runs between the major attractions of polder heritage. The Main Water Connection offers visitors unexpectedly interesting possibilities in water recreation and provides them easy access to the delta area (Fig. 14). Theme Trails, mainly for hiking and biking, 


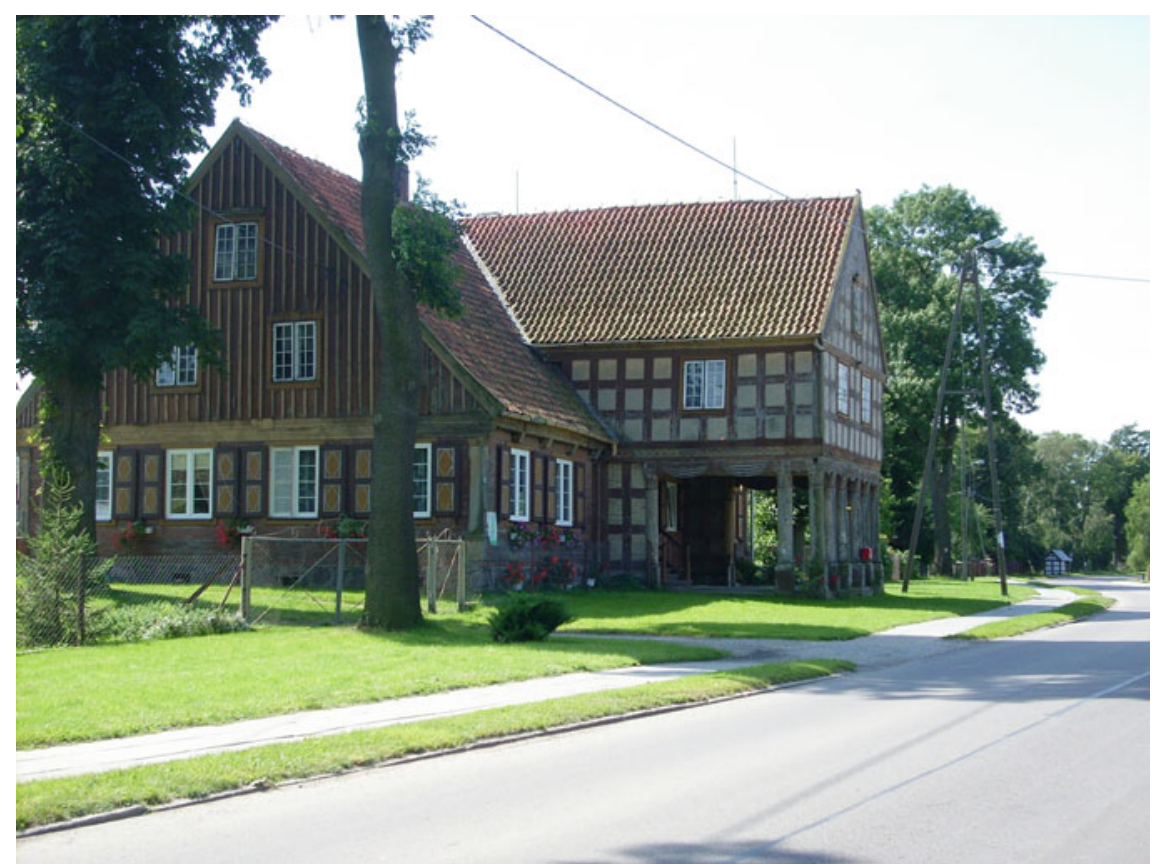

Fig. 9 Farmhouse in Ostaszewo (Schöneberg, Photograph: De Boer); released under a Creative Commons Attribution-NonCommercial-NoDerivatives 4.0 International License

are attractive routes over structures such as dykes, farmland paths, former railway connections (Fig. 15). Long Distance Trails offer a combination of heritage links (use of the historic infrastructure such as roads and waterways), and packages describing hospitality facilities, such as guides, points of interest, water-sport sites, cafes, restaurants, and accommodation options. Thus, the polder is fully equipped to educate and entertain its residents and growing number of guests, in conjunction with information on websites, apps, print media, and regional and national marketing. In addition, the Europolder network offers information at the Polder Information Points about the historical context of the specific polder within the European network. In this way, the Europolder network is the platform for knowledge exchange between the organizations running the different regional networks, mutually reinforcing the regional polder networks in Europe.

\section{Proposed Europolder Network}

The Europolder network will be a partnership among the Netherlands, Belgium, France, Italy, UK, Germany, Poland, and Ukraine. It thus provides a framework for understanding the long interconnected development of European landscapes, and a 


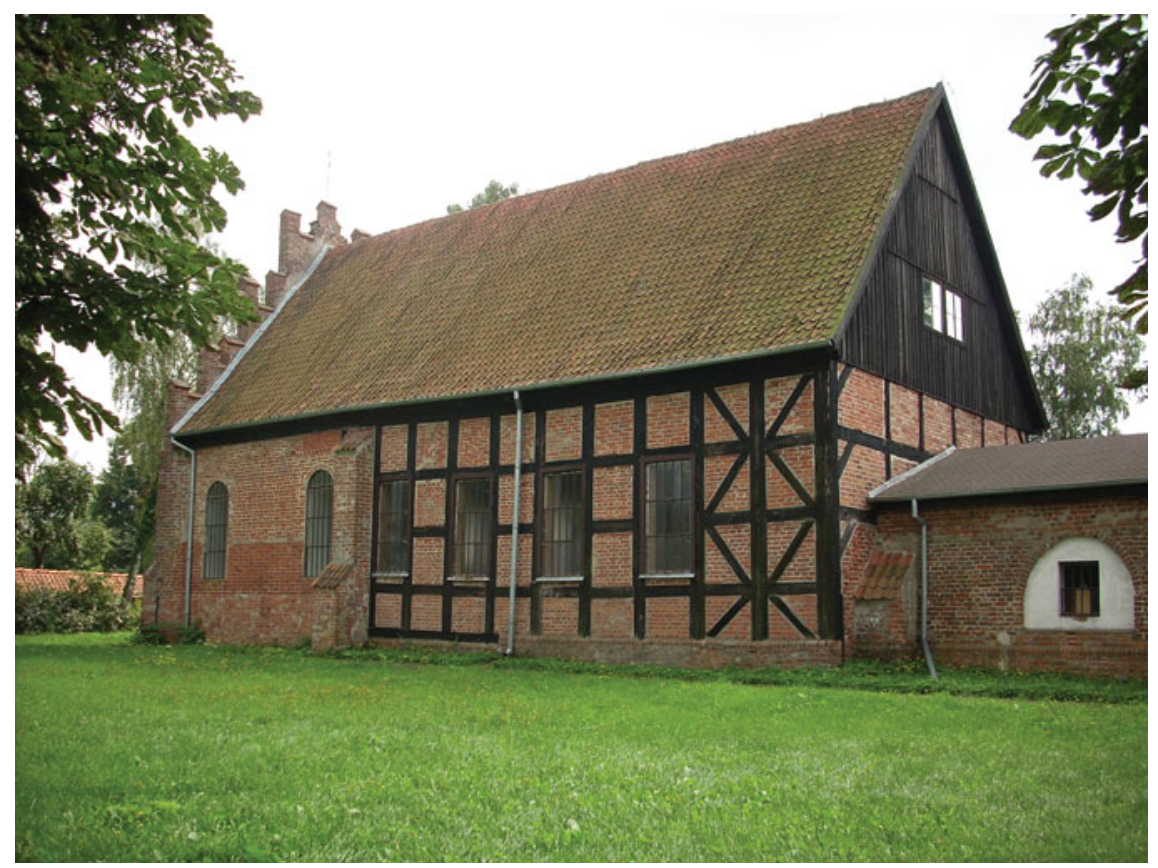

Fig. 10 Mennonite church in Cyganek (Tiegerweide, Photograph: De Boer); released under a Creative Commons Attribution-NonCommercial-NoDerivatives 4.0 International License

means for future cultural integration. Dutch professionals were key players in the shaping of European polders. The area in the Province of Noord-Holland (Figs. 16 and 17), for which in 2013 the Master Plan for the HollandRoute Polderland was developed (De Boer 2013), will become part of the Europolder network, with its characteristic polders, such as Beemster (1612), a UNESCO world heritage site (Fig. 18), Schermer (1635), and Haarlemmermeer (1852). It will be complemented by the Flemish De Moeren polder (Bert Toussaint in Danner et al. 2005, 141-143).

The Europolder network will include at least two polder complexes from each of these areas (De Boer 2015).

The oldest documented Dutch land reclamation outside the Netherlands took place in the basin of the Weser and Elbe. Polders in France, Italy, Poland, and Ukraine were also built with the support of Dutch engineers.

In 1297, settlers from Holland began draining the area of Preussisch Holland (Paslek) (Fig. 19). In 1547, the first Mennonite settlers came to the Danziger and Marienburger Werder. It was the beginning of 250 years of tremendous Mennonite influence in the region of the rivers Vistula and Nogat (Dr. Zbigniew Chodyla in Danner et al. 2005, 33-55). The French King Henri IV (1553-1610) made use of Dutch skills for reclaiming and cultivating wetlands. The Dutch were also involved in reclaiming land from the marshes of the Po Valley (Ferrara, Comácchio, Venetian Territory) in Italy during the sixteenth and seventeenth century. Dutch engineers 


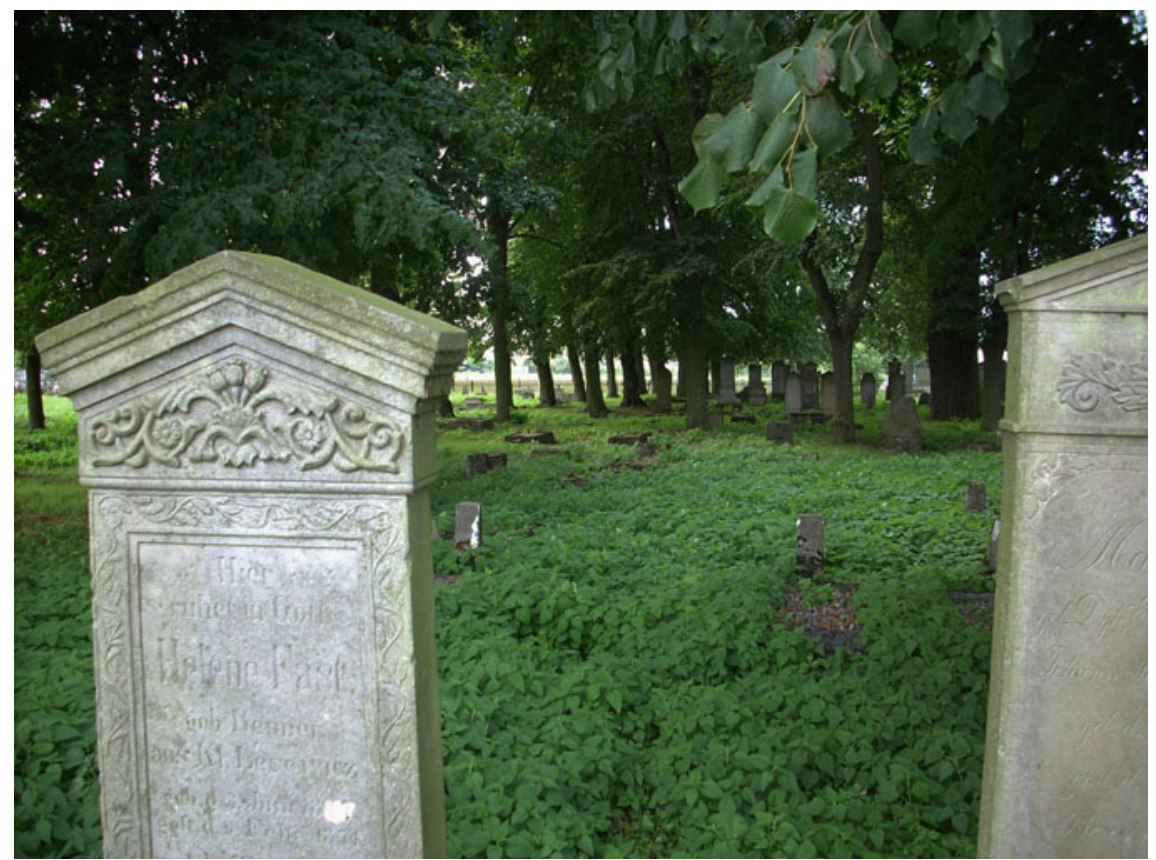

Fig. 11 Mennonite cemetery in Stogi (Heubuden, Photograph: De Boer); released under a Creative Commons Attribution-NonCommercial-NoDerivatives 4.0 International License

Gillis van den Houte (Egidio Vandenhoute) and Everardus van Cortgene (Everardo Corceine) designed successful drainage concepts (Salvatore Ciriacono in Danner et al. 2005, 151-168). Dutchmen were active in England, especially during the reign of King James I (James Charles, 1566-1625) and King Charles I (1600-1649) (Dr. Tom Williamson, in: Danner et al. 2005, 103-119). The Holland Fen (Lincolnshire) was drained by several Dutchmen during the seventeenth century. At the end of the eighteenth century, the Industrial Revolution made its appearance in the polder, with the replacement of windwatermills by steam pumping stations and with that the mechanization of water level management.

The area around Chortyzja in Ukaine, populated by Mennonite settlers from 1788 and after, and the area near the Molotschna River, where Mennonite settlers reclaimed land starting in 1803 (Gerlach 2002, 2007) have been identified as future parts of the Europolder network.

The synchronism between Dutch land reclamation activities in and outside the Netherlands is striking, whereby knowledge and experience were exported to areas where more or less similar conditions were expected. From the development of the windwatermill in the fifteenth century to the weather-independent controllable pumping stations of today, Dutch technology has created and maintained perhaps the most artificial type of landscape in Europe. It is also a truly European cultural landscape, due to the continuing international knowledge exchange for management 


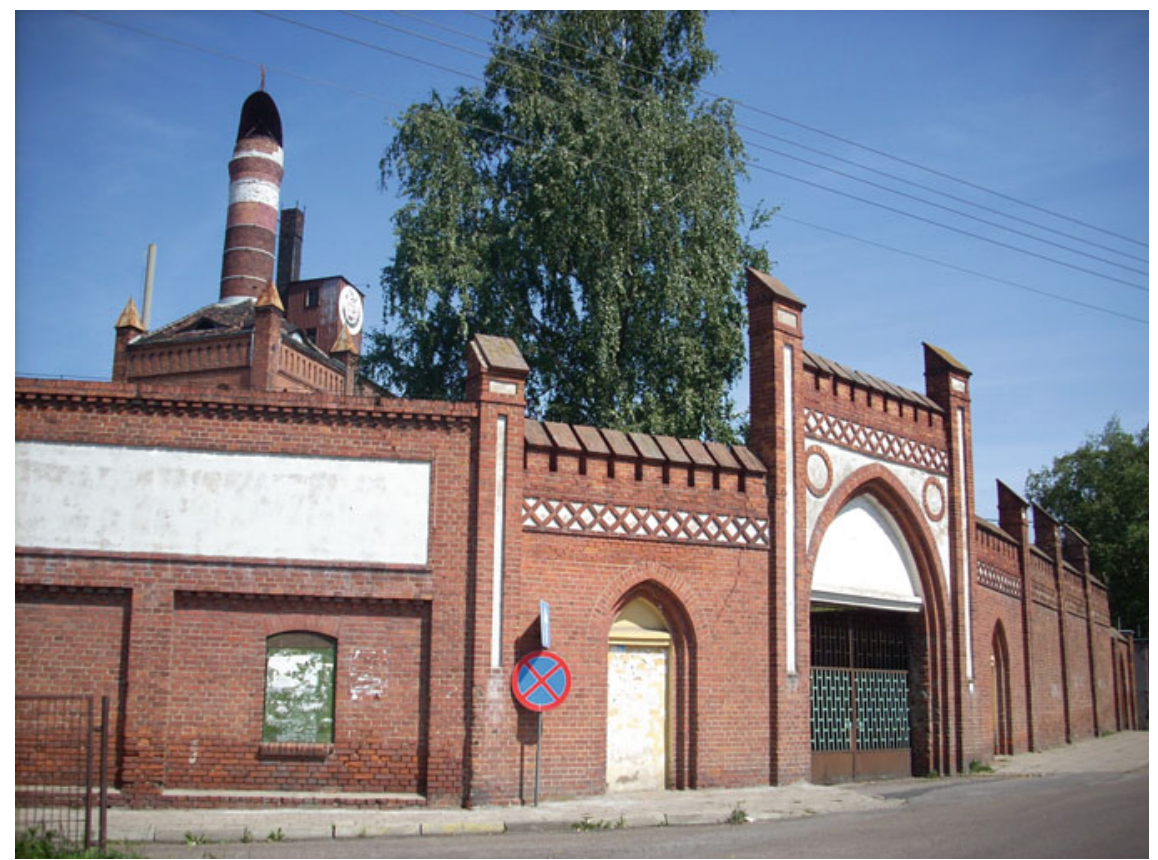

Fig. 12 Former malt factory at Nowy Staw (Neuteich, Photograph: De Boer); released under a Creative Commons Attribution-NonCommercial-NoDerivatives 4.0 International License

and security in relation to climate change. The Dutch Union of Water Authorities within and outside Europe also takes an active position in this, both by responding to the interest in the Dutch water board system and in the innovative promotion of sustainable water management.

The Europolders project highlights the polder landscape as a cultural landscape of land reclamation, as a common and living European cultural heritage. It identifies Europe as the first industrial continent, with its industrial and engineering heritage a result of mutual transnational influences. The Europolder network transmits this cultural European dimension to a broad public through transnational cooperation between a growing number of historically valuable and innovatively controlled polder landscapes, as a celebration of our European heritage.

\section{Conclusion}

Polders can be considered maritime cultural landscapes, intensively connected with water and influenced by it. A polder is not a natural feature and cannot survive on its own; it requires continuous human maintenance. The attributes that the regional Europolder networks use here make up the basic condition for sustaining the polder 


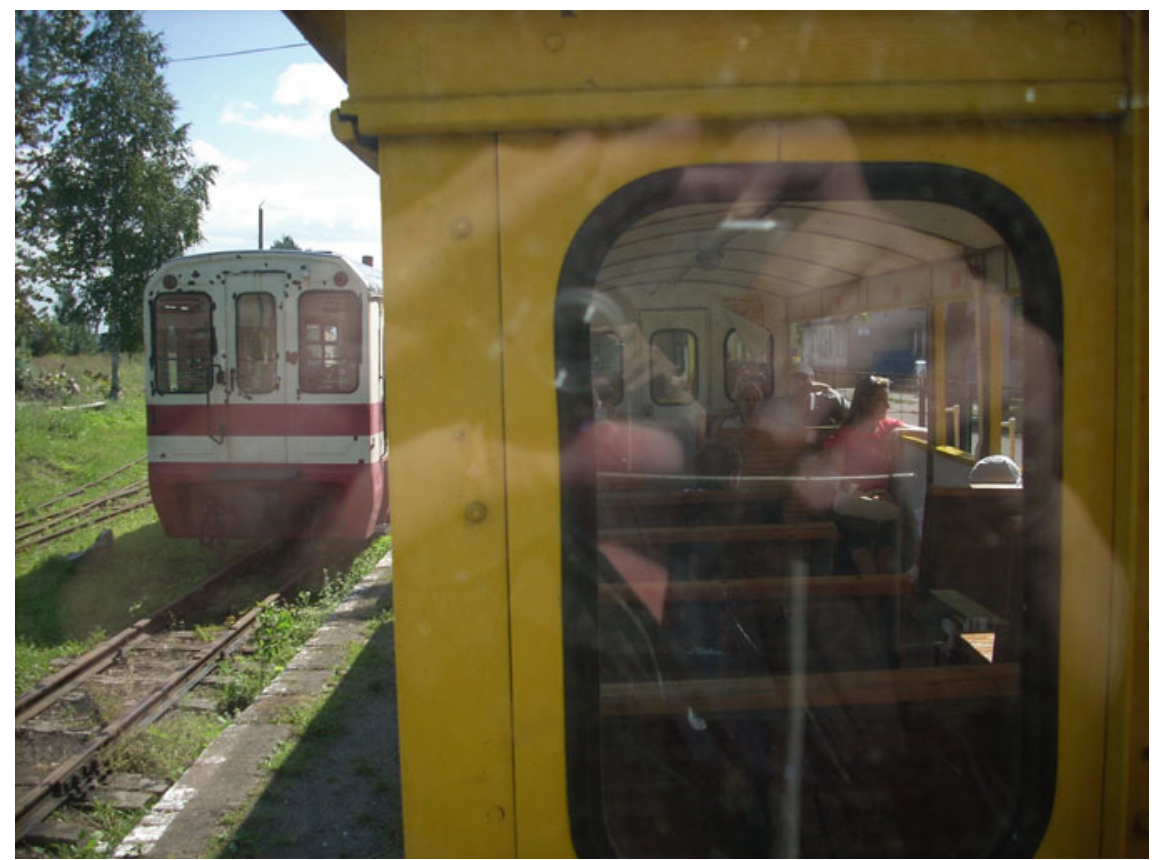

Fig. 13 Narrow gauge railway in Nowy Dwór Gdański (Tiegenhof, Photograph: De Boer); released under a Creative Commons Attribution-NonCommercial-NoDerivatives 4.0 International License

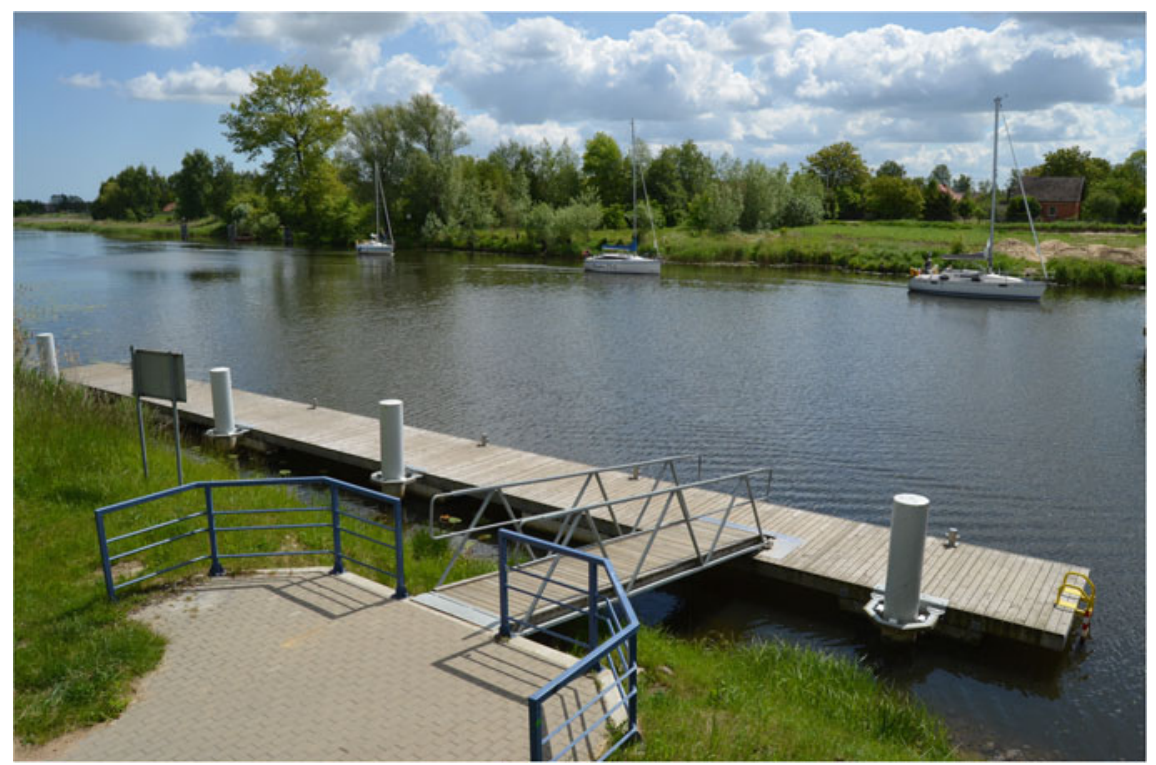

Fig. 14 Main water connection near Drewnica (Schönbaum, Photograph: De Boer); released under a Creative Commons Attribution-NonCommercial-NoDerivatives 4.0 International License 


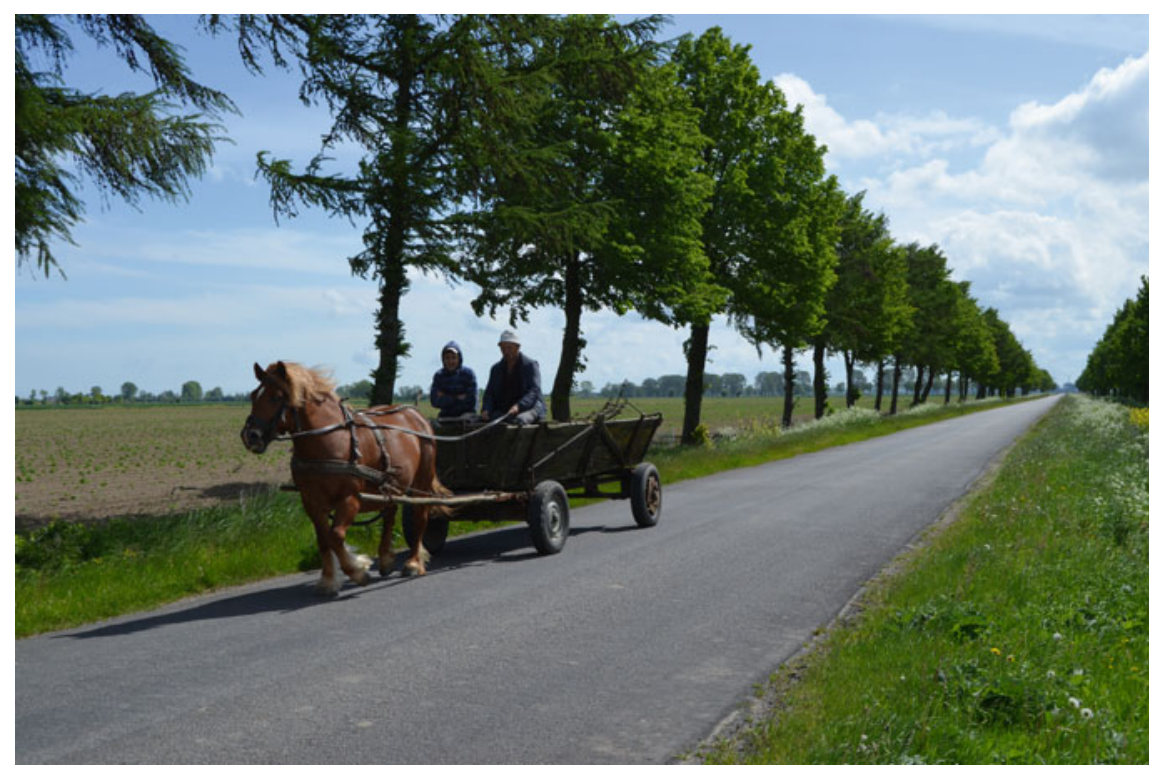

Fig. 15 Quiet trails between Vistula and Nogat (Photograph: De Boer); released under a Creative Commons Attribution-NonCommercial-NoDerivatives 4.0 International License

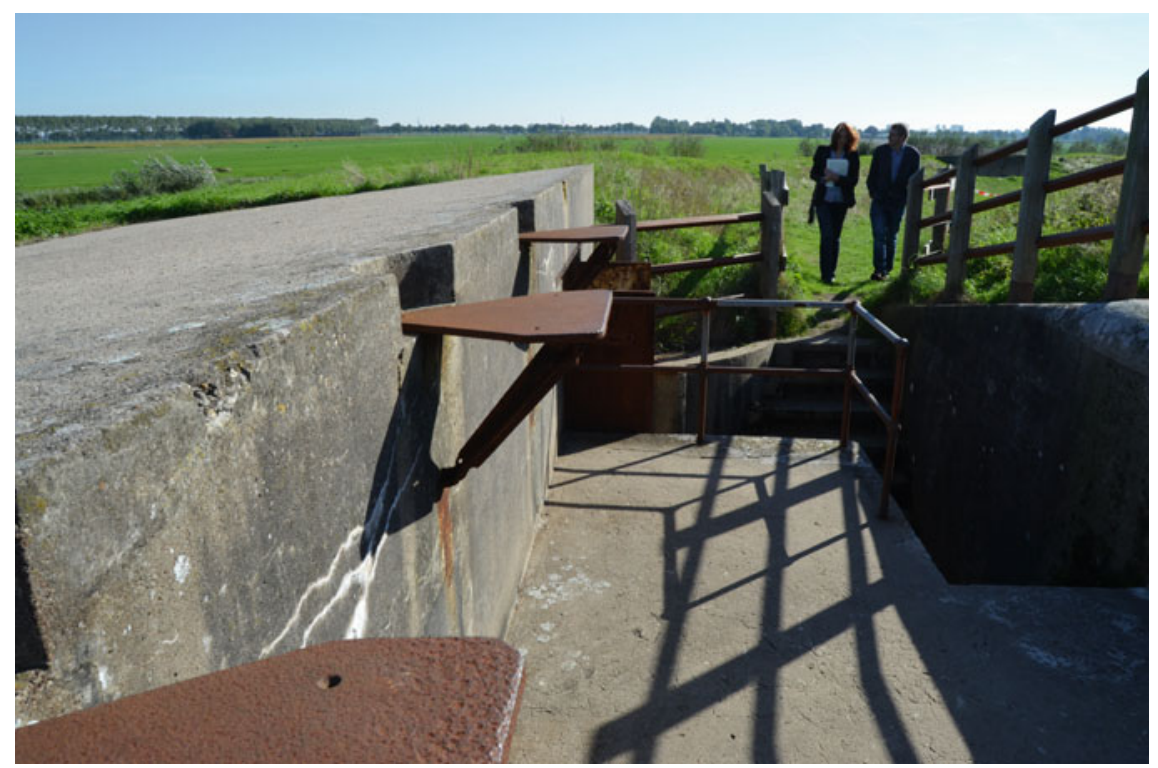

Fig. 16 UNESCO World Heritage Beemster Polder (1612, Photograph: Stichting Werelderfgoed Nederland); released under a Creative Commons Attribution-NonCommercial-NoDerivatives 4.0 International License 


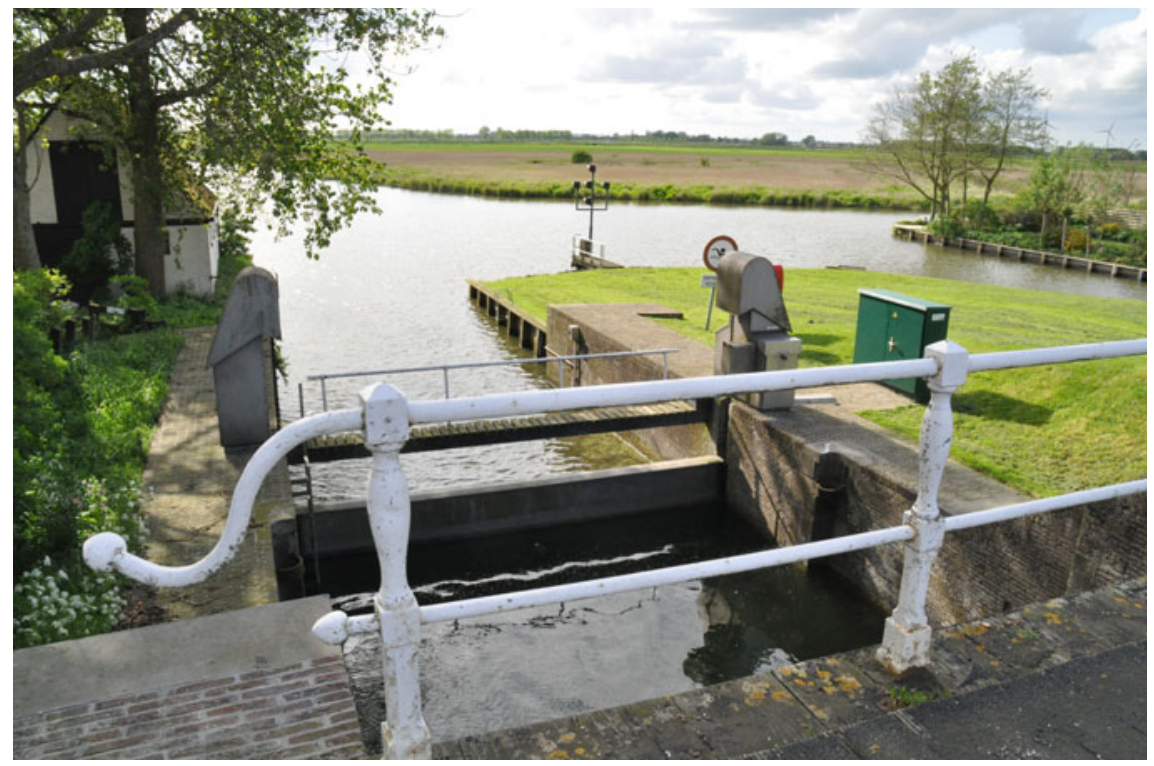

Fig. 17 Schardam, sluice (1592, Photograph: De Boer); released under a Creative Commons Attribution-NonCommercial-NoDerivatives 4.0 International License

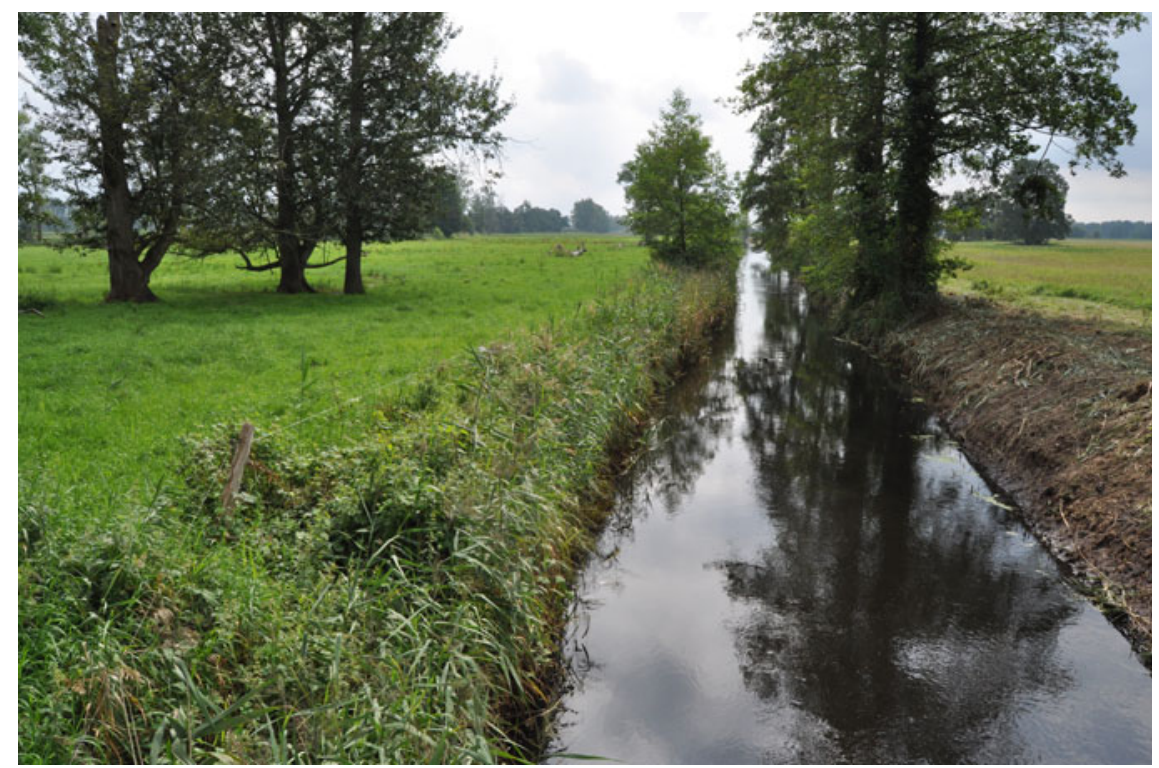

Fig. 18 Brandenburg (Germany), Neuholland (Photograph: De Boer); released under a Creative Commons Attribution-NonCommercial-NoDerivatives 4.0 International License 


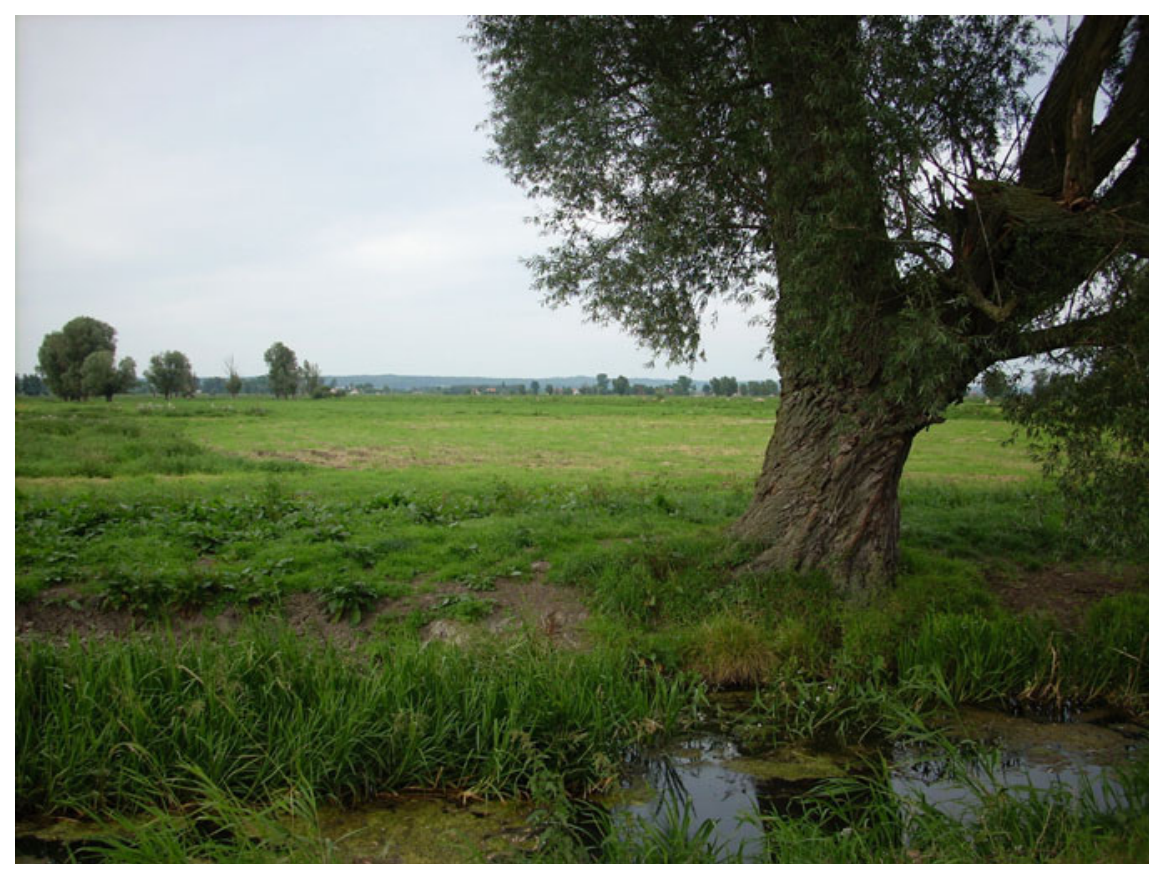

Fig. 19 Dluzyna, near Paslek (Preussisch Holland, Photograph: De Boer); released under a Creative Commons Attribution-NonCommercial-NoDerivatives 4.0 International License

landscape. The first (physical) layer includes historical and current spatial elements that illustrate the story of the formation of the polder. Further, human use of the polder reveals the second (spatial) layer, with aspects such as diversity of land use and the built environment. The attributes used here in the course of time make human life in the artificial landscape tangible. The third (social) layer concerns the interconnectivity of the polder communities as part of a society, with aspects such as innovation, regulation, economic exchange, mutual connections, and hospitality. The combination of hospitality, heritage, and innovative developments in each polder adds up to substantial value for both the domestic population and external visitors.

The Europolders Program aims to intensify this combination, by creating regional heritage and innovation networks with active stakeholders, and by forming a European platform to further increase the awareness of polder landscapes among a wide audience with many different expectations. The resulting public support will confirm local identities and create conditions for local people to further preserve historical values and making contemporary values recognizable. The Europolders Program is an integrated policy that fosters preservation, transformation, and the adaptive reuse of historic water-related structures to economically strengthen communities and help sustain a unique and historically important landscape type. 


\section{References}

de Boer HPG (2015) Europolders, a European Programme on Polder Landscape and Tourism. HollandRoute Foundation, Amsterdam

de Boer HPG (2013) HollandRoute Polderland, Landschap, Erfgoed, Toerisme. HollandRoute Foundation, Amsterdam

Danner HS, Renes J, Toussaint B, van de Ven GP, Zeiler FD (2005) Polder Pioneers, The influence of Dutch engineers on water management in Europe 1600-2000. Utrecht

ERIH (2001) The European route of industrial heritage, the master plan. Duisburg

European Route of Industrial Heritage_-ERIH e.V.: www.erih.net

Gerlach H (2002) Die Rußlandmennoniten I, Ein Volk unterwegs. Kirchheimbolanden

Gerlach H (2007) Die Rußlandmennoniten II, Westpreußen, Rußland und zurück. Band 2, Kirchheimbolanden

HollandRoute Foundation: www.hollandroute.nl

Malanima P (2010) Energy and population in Europe, the Medieval growth (10th-14th centuries). Institute of Studies on Mediterranean Societies (ISSM)/National Research Council (CNR), Roma Van Veen J (1962) Dredge, drain, reclaim: the art of a nation. 5th edn. Den Haag

Hildebrand P. G. de Boer studied History of Art and Archeology at the State University of Groningen, the Netherlands. Since 1983, he has worked in heritage conservation, redevelopment, and tourism, focusing on industrial and water-related heritage. Besides his international work for Europa Nostra, ICOMOS, and the International Committee for the Conservation of Industrial Heritage (TICCIH), De Boer is managing director of the Dutch Foundation for Industrial Culture and the founding vice-president of the European Route of Industrial Heritage (ERIH e.V.).

Open Access This chapter is licensed under the terms of the Creative Commons AttributionNonCommercial-NoDerivatives 4.0 International License (http://creativecommons.org/licenses/bync-nd/4.0/), which permits any noncommercial use, sharing, distribution and reproduction in any medium or format, as long as you give appropriate credit to the original author(s) and the source, provide a link to the Creative Commons license and indicate if you modified the licensed material. You do not have permission under this license to share adapted material derived from this chapter or parts of it.

The images or other third party material in this chapter are included in the chapter's Creative Commons license, unless indicated otherwise in a credit line to the material. If material is not included in the chapter's Creative Commons license and your intended use is not permitted by statutory regulation or exceeds the permitted use, you will need to obtain permission directly from the copyright holder.

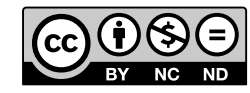

